\title{
HIV Prevention by Oral Preexposure Prophylaxis
}

\author{
Walid Heneine $^{1}$ and Angela Kashuba ${ }^{2}$ \\ ${ }^{1}$ Laboratory Branch, Division of HIV/AIDS Prevention, National Center for HIV, Hepatitis, STD, \\ and Prevention, Centers for Disease Control and Prevention, Atlanta, Georgia 30333 \\ ${ }^{2}$ Division of Pharmacotherapy and Experimental Therapeutics, Eshelman School of Pharmacy, and UNC \\ Center for AIDS Research, University of North Carolina at Chapel Hill, Chapel Hill, North Carolina 27599 \\ Correspondence: wheneine@cdc.gov; akashuba@unc.edu
}

The impressive advances in antiretroviral (ARV) therapy of chronic human immunodeficiency virus (HIV) infections during the last decade and the availability of potent ARV drugs have fueled interest in using chemoprophylaxis as a novel HIV prevention strategy. Preexposure prophylaxis (PrEP) refers to the use of ARV drugs in HIV-negative persons to prevent HIV infection. The rationale for PrEP builds on the success of ARV prophylaxis in preventing mother-to-child transmission of HIV and on a large body of animal studies that show the efficacy of PrEP against mucosal and parenteral infection. We focus on oral administration of ARV drugs for prevention of HIV infection. Identifying an effective prophylactic pill that individuals can take outside the setting of sexual intercourse precludes the necessity to disclose such use to their partners, thereby empowering those who might not be in a position to negotiate with their partners. Several human clinical trials evaluating the efficacy of daily regimens of the HIV reverse-transcriptase (RT) inhibitors tenofovir disoproxil fumarate (TDF) or Truvada (TDF and emtricitabine [FTC]) are under way among high-risk populations. The results of one trial among men who have sex with men showed that daily Truvada was safe and effective, providing the first support for oral PrEP as a prevention strategy. Here we outline the preclinical and clinical research on oral PrEP, pharmacologic considerations, and future directions and challenges.

$\mathrm{T}^{\mathrm{h}, \mathrm{s}}$ he prevention of human immunodeficiency virus (HIV) infection remains a critical public health priority. It is estimated that 2.7 million new HIV infections have occurred worldwide in 2008 at a rate that continues to outpace the rate at which HIV-infected persons enter treatment (UNAIDS 2009). While work on HIV vaccine discovery continues to progress, prevention research has focused in recent years on a variety of new biomedical strategies for preventing infection, such as male circumcision, topical gels containing antiretroviral (ARV) drugs, or preexposure prophylaxis (PrEP) by oral ARV drugs (Padian et al. 2008). PrEP entails providing HIV-negative individuals with oral ARV drugs to prevent HIV acquisition. Since 1995, the continually impressive advances in ARV therapy of HIV-infected individuals and the availability of potent ARV drugs with known safety and potency profiles have fueled interest in using ARV drugs for HIV prevention. The rationale for PrEP is further supported by the

Editors: Frederic D. Bushman, Gary J. Nabel, and Ronald Swanstrom

Additional Perspectives on HIV available at www.perspectivesinmedicine.org

Copyright (C) 2012 Cold Spring Harbor Laboratory Press; all rights reserved; doi: 10.1101/cshperspect.a007419

Cite this article as Cold Spring Harb Perspect Med 2012;2:a007419 
fact that ARV drugs provided to pregnant women with HIV infection were shown to dramatically reduce the risk of perinatal transmission and protect treated breastfed infants of HIV-infected mothers (Hu 2000). Mathematical models estimate that over the next 10 years, an effective PrEP program could prevent 2.73.2 million new HIV-1 infections in subSaharan Africa (Li 2009). This potentially significant public health benefit requires very high PrEP efficacy, which might be lost or substantially reduced with a PrEP efficacy of $<50 \%$. Therefore, identifying highly effective PrEP modalities is critical. In this work we provide an overview of oral PrEP for HIV prevention, discuss ARV drug selection and pharmacology, animal studies, current clinical trials, and implementation planning.

\section{EARLY EVENTS IN HIV TRANSMISSION AND IMPLICATIONS FOR PrEP}

The current understanding of mucosal HIV transmission suggests that HIV first replicates at a low level at the mucosal point of entry in the new host. PrEP can be designed to exploit this brief period of virus vulnerability and block HIV from establishing itself as a persistent infection. Early infection events have been largely derived from monkey model studies of vaginal infection with the simian immunodeficiency virus (SIV) (Haase 2005). These studies have consistently shown that, after penetration of SIV into the cervicovaginal epithelium, infection in cervicovaginal tissues during the first $1-3 \mathrm{~d}$ is limited to extremely small numbers of productively infected cells in rare foci ( $\mathrm{Hu}$ et al. 2000; Miller et al. 2005; Li et al. 2009). This small local founder population of infected cells expands in the following days, possibly by accretion of new infections around the initial clusters (Li et al. 2009). Continuous expansion at the point of entry and dissemination of both virus and infected cells through lymphatic drainage and the bloodstream establishes a sustainable infection in secondary lymphoid organs (Miller et al. 2005). In $<2 \mathrm{wk}$, a very small founder population of productively infected cells at the portal of entry progresses to systemic infection with a burst of virus production and depletion of gut $\mathrm{CD} 4^{+} \mathrm{T}$ cells. At this point, a robust virus-specific immune response can contain viral replication only to a certain degree (Reynolds et al. 2005). Thus, the first days of infection at the mucosa when replication is limited to small clusters of infected cells are the periods of maximum virus vulnerability and represent a window of opportunity for intervention. Mucosal HIV infection can be conceivably prevented by a rapid and efficient host immune response or by limiting the size of founder populations of infected cells to a theoretical threshold under which infection cannot be established. HIV vaccines have so far been unable to elicit highly protective immune responses. Anti-inflammatory agents that interfere with innate host responses and limit expansion of founder populations have shown promising results in macaques, although the existence of occult infections is still a possibility (Li et al. 2009). However, by inhibiting key steps in HIV replication such as entry or reverse transcription, ARV drugs delivered by oral PrEP may conceivably block the establishment of founder populations of infected cells, or prevent their expansion leading to a dead-end infection. As described below, data from animal models and also from a recent human trial support the promise of this prevention strategy.

\section{ARV DRUGS FOR ORAL PrEP}

Beyond mechanical barriers, there are only two biological strategies to prevent HIV infection at the moment of exposure: modification of a host defense (such as a vaccine stimulating neutralizing antibodies) and/or the use of ARV therapy to saturate the cells receptive to HIV infection and replication. The significance of finding a drug, or drug combination, that people can control and use intermittently to protect them against HIV acquisition is immense. In order to choose an effective ARV regimen for PrEP, investigators must choose the right drugs, which target the right sites of infection in the right concentration for the right amount of time. 


\section{The Right Drug}

Drug candidates for oral PrEP have largely been selected from currently approved drugs for treatment of individuals infected with HIV-1 because development of drugs exclusively for HIV prevention has been limited. There are currently $>30$ drugs or drug combinations that have been approved for treatment of HIV (Department of Health and Human Services Panel on Antiretroviral Guidelines for Adults and Adolescents January 10, 2011), and a number of desirable drug characteristics for PrEP overlap with those for treatment: good tolerability, low pill burden, infrequent dosing, and resistance profiles with minimal cross resistance. Preintegration drugs (chemokine receptor antagonists, nucleoside and nonnucleoside analog reverse-transcriptase inhibitors, and integrase inhibitors) are currently thought to be more suitable than postintegration drugs (protease inhibitors, maturation inhibitors) for prevention, although direct evidence to support this assumption is lacking.

One pharmacokinetic property considered important for PrEP drugs targeting sexual transmission includes the ability to rapidly reach and accumulate in genital and rectal tissues. Antiretrovirals differ greatly in their ability to penetrate mucosal tissues or secretions (Cohen et al. 2007; Dumond et al. 2007, 2009; Jones et al. 2009; Brown et al. 2011). In general, highly protein-bound compounds do not gain access to these secondary compartments because of their affinity for plasma proteins such as albumin and $\alpha_{1}$-acid glycoprotein. Drugs such as the protease inhibitors, which are $95 \%-99 \%$ bound to plasma proteins, generally achieve female genital tract concentrations $<50 \%$ those in the plasma (Nicol and Kashuba 2010). In contrast, most nucleoside-analog reverse-transcriptase inhibitors (NRTIs) have a low degree of protein binding $(<0.7 \%-49 \%)$ and achieve concentrations two- to sixfold higher in mucosal tissue than in plasma.

However, plasma protein binding is not the only predictor of ARV exposure. For example, maraviroc, a cellular entry inhibitor that shows $75 \%$ protein binding in blood plasma, has high penetration into cervicovaginal fluid (CVF) and
HIV Prevention by Oral Preexposure Prophylaxis

vaginal tissue. After $7 \mathrm{~d}$ of dosing at $300 \mathrm{mg}$ of maraviroc twice daily, the areas under the concentration-time curve (AUCs) in CVF and vaginal tissue are 2.7 and 1.9 times higher, respectively, than blood plasma (Dumond et al. 2009). Raltegravir, an integrase inhibitor that is $83 \%$ protein bound in plasma, has also been shown to penetrate well in the female genital tract: The concentrations of the drug in CVF after multiple dosing are up to twofold higher than those in plasma (Jones et al. 2009). Figure 1 summarizes all available data of antiretroviral penetration into cervicovaginal fluid, cervical and vaginal tissues, and rectal tissues.

One additional factor relating ARV pharmacokinetics to efficacy at mucosal surfaces is protein binding within the mucosal secretions themselves. The concentrations of albumin and $\alpha_{1}$-acid glycoprotein in cervicovaginal fluid are $<1 \%$ of the values in plasma (Salas Herrera et al. 1991). Although the protein binding of drugs in genital secretions has not been extensively evaluated, maraviroc has recently been shown to have 10 -fold less protein binding in CVF than in plasma (7.5\% vs. $75 \%$ ) (Dumond et al. 2009). This phenomenon must be considered in pharmacokinetic-pharmacodynamic analysis of ARV prevention strategies, as the free drug concentration represents the fraction of drug available to be active against HIV infection. Therefore, even though total drug concentration may be lower than blood plasma in mucosal secretions, the free drug concentration may be similar to, or higher than, these plasma concentrations.

The extent of penetration of drugs into rectal tissues also has implications for HIV transmission. Data in these tissues are sparse, but are available for some nucleoside-analog reversetranscriptase inhibitors (NRTI), nonnucleosideanalog reverse-transcriptase inhibitors (NNRTI), protease inhibitors (PI), and entry inhibitors. Taken orally, tenofovir and emtricitabine concentrate in rectal tissues, achieving concentrations 33- and fourfold greater than plasma. Exposures $\left(\mathrm{AUC}_{12 \mathrm{~h}}\right)$ of maraviroc are $\sim 30$ times higher in rectal tissues than in plasma (Brown et al. 2011). Darunavir, etravirine, and ritonavir have exposures three-, seven-, and 13-fold higher than plasma. 
W. Heneine and A. Kashuba
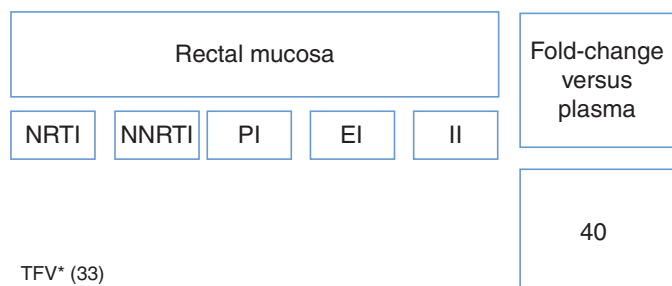

40

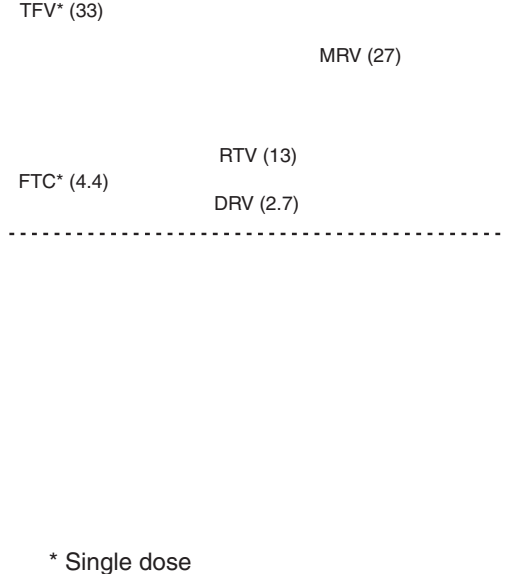

40

30

20

10

Equivalent

0.75

0.5

0.25

0
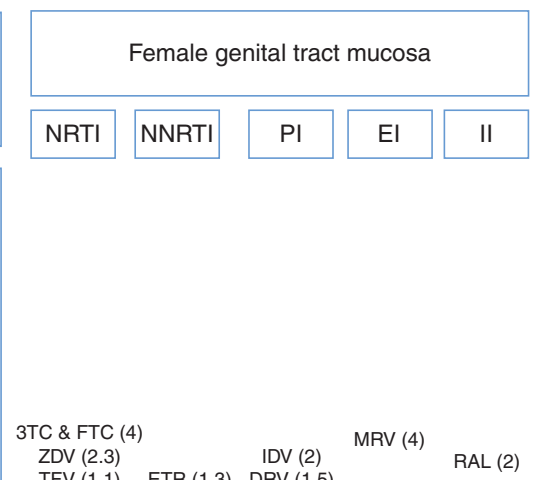

$\begin{array}{ccc}\text { ZDV (2.3) } & \text { IDV (2) } & \text { RAL } \\ \operatorname{TFV}(1.1) & \text { ETR (1.3) } & \text { DRV (1.5) }\end{array}$

$\operatorname{NVP}(0.8)$

APV (0.5)

RTV (0.3)

ddl (0.2) DLV (0.2) ATV (0.2)

$\begin{array}{lll}\text { ABC }(0.08) & \operatorname{LPV}(0.08) \\ \text { d4T (0.05) } & \text { EFV (0.04) } & \operatorname{SQV}(0)\end{array}$

Figure 1. Penetration of oral antiretrovirals into mucosal surfaces. Blood plasma AUC ratios of tissue or mucosal secretions under steady-state conditions relative to blood plasma are reported unless otherwise marked. The dotted line represents drug concentrations in tissue or secretions equivalent to blood plasma. Drugs falling above the line concentrate at mucosal surfaces. Drugs falling below the line achieve concentrations at mucosal surfaces lower than blood plasma. The number in parentheses represents the ratio of mucosal surface AUC to blood plasma AUC. NRTI, nucleoside-analog reverse-transcriptase inhibitors; NNRTI, nonnucleoside-analog reverse-transcriptase inhibitors; PI, protease inhibitors; EI, entry inhibitors; II, integrase inhibitors TFV (tenofovir); FTC (emtricitabine); 3TC (lamivudine); ZDV (zidovudine); ddI (didanosine); ABC (abacavir); d4T (stavudine); ETR (etravirine); NVP (nevirapine); DLV (delavirdine); EFV (efavirenz); IDV (indinavir); RTV (ritonavir); DRV (darunavir); APV (amprenavir); LPV (lopinavir); ATV (atazanavir); SQV (saquinavir); MRV (maraviroc); RAL (raltegravir).

The nucleoside/tide analogs require cellular uptake and phosphorylation to be active against the RT enzyme. Intracellular concentrations of tenofovir diphosphate and emtricitabine triphosphate have been recently evaluated in cervical, vaginal, and rectal tissues after a single dose (Patterson et al. 2010). The accumulation of tenofovir diphosphate and emtricitabine triphosphate was wide-ranging depending on tissue type. In rectal tissue, the exposure of tenofovir diphosphate was 100-fold higher than in vaginal or cervical tissue. Yet in vaginal and cervical tissue, the exposure of FTC was 10 -fold higher than in rectal tissue. In all tissues, emtricitabine triphosphate was not detectable beyond $2 \mathrm{~d}$ postdose. These results provide one plausible pharmacologic explanation for the recent disappointing results from the FEMPrEP trial with Truvada (Matassa 2011) (see below). This study was stopped prematurely for futility. FEM PrEP used the same daily dosing of Truvada, which showed $44 \%$ efficacy in preventing HIV transmission in men who have sex with men, but enrolled only high-risk women. These results show the need for a better understanding between ARV exposure in mucosal tissues and protection from HIV infection.

\section{The Right Site}

Over the past few years the HIV transmission event has become increasingly well understood (Berger et al. 1999; Keele et al. 2008; Keele and 
Derdeyn 2009). This information is critical for designing effective strategies for HIV prevention. The most current evidence suggests the initial target of the transmitted/founder virus at mucosal sites is a $\mathrm{CD}_{4}^{+} \mathrm{T}$ cell expressing high levels of CCR5 and $\alpha_{4} \beta_{7}$ receptors (Chun et al. 1998). A strategy targeting these cells within vulnerable mucosal tissues (vaginal, cervical, and colorectal) may assist in selecting certain drugs for HIV prevention strategies. For example, orally administered drugs that reach these tissues in high concentrations for an extended period of time and target these specific cells would be preferentially selected for further development.

\section{The Right Concentration}

The target drug exposure required for preventing HIV infection at human mucosal surfaces is unknown. Therefore, the working assumption is that higher drug exposures are better at conferring protection. Although human trials will ultimately determine whether tissue concentrations achieved with oral drug dosing can prevent HIV transmission, preclinical research (animal studies and human tissue culture experiments) can provide valuable information and can guide the next steps in the research and practice of PrEP. These models can evaluate potential cell populations/subpopulations that are not adequately protected by current PrEP regimens, can help to define better drug regimens that include other drug classes such as entry inhibitors, and can evaluate the effect of drug-resistant viruses on protective efficacy (Veazey et al. 2005).

Performing early dose-ranging tissue concentration studies in phase I pharmacokinetic investigations, coupled with a preclinical understanding of concentration targets required to prevent HIV infection, allows for an optimal selection of drugs, doses, and dosing frequency to be implemented in later stage clinical trials. These studies should evaluate not only drug penetration in rectal and vaginal tissues, but also the degree of drug exposure in cells that are primary targets during early mucosal infection such as activated/resting T cells, dendritic
HIV Prevention by Oral Preexposure Prophylaxis

cells, or Langerhans cells. As an example, the threshold for concentrations of TFV-DP and FTC-TP that results in tissue protection has not been absolutely defined in macaques or tissue explants. These data, coupled with the knowledge of how drugs behave in tissues with certain dosing strategies, can be used to determine the minimal dose and dose frequency required for protection, which can then be used to optimize phases II and III clinical trial design.

One such dose-ranging tissue concentration study currently ongoing is HPTN 066 within the HIV Prevention Trials Network: This multisite phase I study is scheduled to be completed in 2011. It involves four different treatment regimens in HIV-negative men and women (arm 1: $300 \mathrm{mg}$ TDF/200 mg FTC weekly; arm 2: $300 \mathrm{mg}$ TDF/200 mg FTC twice weekly; arm 3: $600 \mathrm{mg} \mathrm{TDF} / 400 \mathrm{mg}$ FTC twice weekly; and arm 4: $300 \mathrm{mg}$ TDF/200 mg FTC daily). Sampling of rectal, seminal, and vaginal fluids, plasma, cells, and tissues will be performed to assess the dose proportionality of intracellular phosphorylated metabolites of TFV and FTC and to quantify their intraindividual variability. The information from this study will fill a large gap in the knowledge of intracellular kinetics of these medications at multiple mucosal surfaces and will help identify the time periods during which specific dosing strategies confer protection, once target concentrations are identified (using in vitro, animal, or clinical study data). Quantification of the intra-individual variability will enable future studies to use drug concentrations as a determinant of adherence to medication regimens-a critical component to interpret the findings of HIV prevention studies, which remains suboptimal.

\section{The Right Amount of Time}

Infection of HIV in mucosal tissues occurs quickly. These data are reviewed in detail in Shaw and Hunter (2011). Knowing that an initial round of HIV replication can occur in mucosal tissue within $24 \mathrm{~h}$ of exposure suggests that antiretroviral drugs need to be at the site of infection before, or very shortly after, HIV 
exposure. Additionally, data demonstrating recoverable infectious virus up to $8 \mathrm{~d}$ after inoculation of cervical tissue cultures suggest that significant drug exposure may need to be available for days after exposure (Collins et al. 2000). Particular emphasis is being placed on longeracting drug formulations for next-generation PrEP agents (vaginal rings, intramuscular depot injections), which will require less frequent dosing and could be taken independently of virus exposure.

\section{PRECLINICAL RESEARCH IN ANIMAL MODELS}

The potential use of antiretroviral drugs for HIV prophylaxis has been studied extensively in nonhuman primate models of mucosal and parenteral SIV or SHIV (SIV/HIV chimera) transmission and, more recently, in humanized mouse models (Table 1). Early work with subcutaneous TFV in macaques showed the first proof-of-concept data on the efficacy of ARV prophylaxis against intravenous virus inoculation (Tsai et al. 1995). Subsequent work showed that postexposure prophylaxis with TFV can protect against intravenous SIV inoculation and helped define the optimal timing for initiating ARV therapy and the need for a $4 \mathrm{wk}$ treatment to achieve protection (Tsai et al. 1998). Indications that ARV drugs administered before exposure could also prevent oral SIV infection came from studies that used different doses of TFV (Van Rompay et al. 1998, 2006). More recently, repeat low-dose macaque models of mucosal transmission have been developed and used to assess PrEP efficacy of different ARV regimens and modalities (Otten et al. 2005; Subbarao et al. 2006). These models closely mimic human transmission of HIV in many aspects, including the use of a lower and more physiologic virus inoculum than that used in conventional single high-dose challenge models. In addition, the SHIV challenge contains an R5-tropic HIV-1 $1_{\mathrm{SF} 162}$ envelope similar to naturally transmitted viruses. Virus exposures are repeated to mimic high-risk human exposures, thereby providing the opportunity to measure protection against multiple transmission events in each animal (Subbarao et al. 2006; Garcia-Lerma et al. 2008; Keele and Derdeyn 2009). Using such a model of rectal infection to assess the efficacy of TDF, FTC, or TDF/ FTC combination at human equivalent dosing, it was found that daily TDF provided little protection, whereas FTC reduced risk by 3.8 -fold (Subbarao et al. 2006, Garcia-Lerma et al. 2008, 2010). In contrast, TDF/FTC combination was more protective and provided a nearly eightfold lower risk of infection; a higher FTC/TFV dose afforded full protection (Garcia-Lerma et al. 2008). These experiments showed a dose-response relationship and suggested that TDF/FTC may be more effective than either TDF or FTC alone against rectal infection. Data on PrEP efficacy against vaginal challenges in macaques are not available. These studies are important because similar to what is observed in humans, oral Truvada in macaques achieves different drug exposures in vaginal tissues than in rectal tissues. However, data from a humanized mouse model showed that a high dose of TDF/FTC combination administered intraperitoneally protected mice against a vaginal HIV infection (Denton et al. 2008). Recent findings also showed that oral PrEP with either raltegravir or maraviroc protected humanized mice from vaginal HIV infection (Neff et al. 2011), although drug concentrations were not measured.

Several important observations of potential relevance to humans have been made from the analysis of PrEP breakthrough infections in macaques. First, drug resistance can emerge if ARV therapy continues after PrEP fails. In one macaque study, two of six animals infected during daily PrEP with FTC or Truvada showed selection for drug-resistant viruses (GarciaLerma et al. 2008). In both macaques, the M184V mutation associated with FTC resistance was selected, thus reiterating the importance of closely monitoring PrEP failures to minimize drug-resistance emergence. Second, PrEP breakthroughs during FTC and Truvada treatment had lower acute viremias than control animals. A reduction in viremia during PrEP might conceivably contribute to a decrease in HIV-1 transmissibility at the population level 


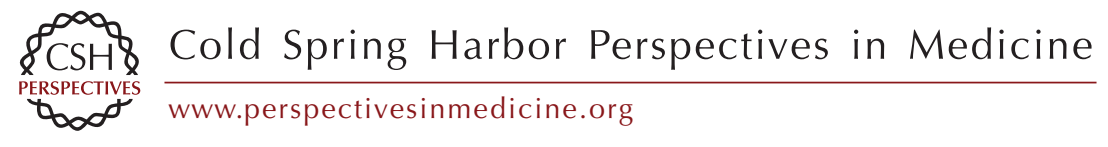

Table 1. Efficacy of preexposure prophylaxis modalities in animal models of mucosal and intravenous infection

\begin{tabular}{|c|c|c|c|c|c|c|}
\hline Reference & Animal & Drugs and dose & $\begin{array}{l}\text { Route of drug } \\
\text { administration }\end{array}$ & $\begin{array}{l}\text { Virus exposure and } \\
\text { dose }\end{array}$ & Interventions & Main findings \\
\hline Tsai et al. 1995 & $\begin{array}{l}\text { Long-tailed } \\
\text { macaques }\end{array}$ & $\mathrm{TFV}, 20 \mathrm{mg} / \mathrm{kg}$ & Subcutaneous & $\begin{array}{l}\text { Single intravenous } \\
\text { exposure to } \\
\text { SIV }_{\text {mne }}\left(10^{3}\right. \\
\left.\operatorname{TCID}_{50}\right)\end{array}$ & $\begin{array}{l}\text { TFV initiated } 48 \mathrm{~h} \text { before exposure } \\
\text { and continued for } 4 \mathrm{wk}\end{array}$ & Full protection \\
\hline $\begin{array}{r}\text { Van Rompay } \\
\text { et al. } 1998\end{array}$ & $\begin{array}{l}\text { Rhesus } \\
\text { macaques }\end{array}$ & $\mathrm{TFV}, 30 \mathrm{mg} / \mathrm{kg}$ & Subcutaneous & $\begin{array}{l}\text { Oral, SIVmac } 251 \\
\quad\left(10^{5} \mathrm{TCID}_{50}\right)\end{array}$ & $\begin{array}{l}\text { Two doses given } 4 \mathrm{~h} \text { before and } 24 \mathrm{~h} \\
\text { after }\end{array}$ & Full protection \\
\hline $\begin{array}{r}\text { Van Rompay } \\
\text { et al. } 2006\end{array}$ & $\begin{array}{l}\text { Rhesus } \\
\text { macaques }\end{array}$ & $\begin{array}{l}\text { TDF, } 0.01- \\
0.02 \mathrm{mg} / \mathrm{kg}\end{array}$ & Oral & $\begin{array}{l}\text { Multiple oral } \\
\text { exposures to } \\
\text { SIVmac251 }\left(10^{4}\right. \\
\left.\text { TCID }_{50}\right)\end{array}$ & $\begin{array}{l}\text { TDF initiated } 1 \mathrm{~d} \text { before exposure } \\
\text { and maintained during } \\
\text { continuous virus inoculations; } \\
\text { one additional dose after the last } \\
\text { virus exposure }\end{array}$ & $\begin{array}{l}\text { No protection; low doses of } \\
\text { TDF }\end{array}$ \\
\hline $\begin{array}{r}\text { Van Rompay } \\
\text { et al. } 2006\end{array}$ & $\begin{array}{l}\text { Rhesus } \\
\text { macaques }\end{array}$ & TDF, $10 \mathrm{mg} / \mathrm{kg}$ & Oral & $\begin{array}{l}\text { Multiple oral } \\
\text { exposures to } \\
\text { SIVmac251 }\left(10^{5}\right. \\
\left.\text { TCID }_{50}\right)\end{array}$ & $\begin{array}{l}\text { Repeated cycles of daily TDF } \\
\text { initiated } 1-2 \mathrm{~d} \text { before exposure }\end{array}$ & $\begin{array}{l}\text { Partial prophylactic efficacy; } \\
\text { infection associated with low } \\
\text { systemic drug exposures }\end{array}$ \\
\hline $\begin{array}{l}\text { Subbarao et al. } \\
\quad 2006\end{array}$ & $\begin{array}{l}\text { Rhesus } \\
\text { macaques }\end{array}$ & TDF, $22 \mathrm{mg} / \mathrm{kg}$ & Oral & $\begin{array}{l}\text { Repeated low-dose } \\
\text { atraumatic rectal } \\
\text { exposures to } \\
\text { SHIV }_{162 \mathrm{p} 3}(10 \\
\left.\text { TCID }_{50}\right)\end{array}$ & Daily or weekly TDF & $\begin{array}{l}\text { All controls animals infected } \\
\text { after } 1.5 \text { exposures; } 3 \text { of } 4 \\
\text { TDF-treated animals } \\
\text { infected after } 6-7 \text { exposures }\end{array}$ \\
\hline $\begin{array}{l}\text { García-Lerma } \\
\text { et al. } 2008\end{array}$ & $\begin{array}{l}\text { Rhesus } \\
\text { macaques }\end{array}$ & $\begin{array}{l}\text { FTC, } 20 \mathrm{mg} / \mathrm{kg} \\
\text { TDF, } 22 \mathrm{mg} / \\
\mathrm{kg} ; \mathrm{TFV} \\
20 \mathrm{mg} / \mathrm{kg}\end{array}$ & $\begin{array}{l}\text { Oral (Truvada) or } \\
\text { subcutaneous } \\
\text { (FTC, TFV) }\end{array}$ & $\begin{array}{l}\text { Repeated low-dose } \\
\text { atraumatic rectal } \\
\text { exposures to } \\
\text { SHIV }_{162 \mathrm{p} 3}(10 \\
\left.\text { TCID }_{50}\right)\end{array}$ & $\begin{array}{l}\text { Daily FTC (subcutaneous); } \\
\text { daily oral Truvada; } \\
\text { daily or intermittent FTC/TFV } \\
\text { (subcutaneous) }\end{array}$ & $\begin{array}{l}\text { Risk of infection reduced with } \\
\text { human equivalent doses of } \\
\text { FTC (fourfold) and Truvada } \\
\text { (eightfold); no infection } \\
\text { with FTC and high TFV } \\
\text { doses (daily or intermittent) }\end{array}$ \\
\hline
\end{tabular}

Continued 


\section{$8_{\mathrm{CSH}}^{\infty}$ Cold Spring Harbor Perspectives in Medicine \\ PESPECTIVES www.perspectivesinmedicine.org}

Table 1. Continued

\begin{tabular}{|c|c|c|c|c|c|c|}
\hline Reference & Animal & Drugs and dose & $\begin{array}{l}\text { Route of drug } \\
\text { administration }\end{array}$ & $\begin{array}{l}\text { Virus exposure and } \\
\text { dose }\end{array}$ & Interventions & Main findings \\
\hline $\begin{array}{l}\text { Denton et al. } \\
2008\end{array}$ & $\begin{array}{l}\text { Humanized } \\
\text { mice }\end{array}$ & $\begin{array}{l}\text { FTC, } 3.5 \mathrm{mg} \\
\text { TDF, } 5.2 \mathrm{mg}\end{array}$ & Intraperitoneal & $\begin{array}{l}\text { Single atraumatic } \\
\text { intravaginal } \\
\text { exposure to } \\
\text { HIV- }_{\text {JR-CSF }}\left(10^{5}\right. \\
\left.\text { TCID }_{50}\right)\end{array}$ & $\begin{array}{c}\text { Daily FTC/TDF initiated } 48 \text { h before } \\
\text { exposure and continued for } 7 \mathrm{~d}\end{array}$ & Full protection \\
\hline $\begin{array}{l}\text { García-Lerma } \\
\text { et al. } 2010\end{array}$ & $\begin{array}{l}\text { Rhesus } \\
\text { macaques }\end{array}$ & $\begin{array}{l}\text { FTC, } 20 \mathrm{mg} / \mathrm{kg} \\
\text { TDF, } 20 \mathrm{mg} / \\
\mathrm{kg}\end{array}$ & Oral & $\begin{array}{l}\text { Repeated low-dose } \\
\text { atraumatic rectal } \\
\text { exposures to } \\
\text { SHIV }_{162 \mathrm{p} 3}(10 \\
\left.\text { TCID }_{50}\right)\end{array}$ & $\begin{array}{l}\text { Event-driven and } \\
\text { exposure-independent } \\
\text { intermittent Truvada dosing }\end{array}$ & $\begin{array}{l}\text { High to moderate efficacy with } \\
2 \text { weekly human equivalent } \\
\text { doses of Truvada given at } \\
\text { different intervals }\end{array}$ \\
\hline Neff et al. 2010 & $\begin{array}{l}\text { Humanized } \\
\text { mice }\end{array}$ & $\begin{array}{l}\text { Raltegravair } \\
\qquad(164 \mathrm{mg} / \mathrm{kg}) \\
\text { or Maraviroc } \\
(62 \mathrm{mg} / \mathrm{kg})\end{array}$ & Oral & $\begin{array}{l}\text { Single high-dose } \\
\text { HIV-1 ( } 3000 \\
\text { TCID) }\end{array}$ & $\begin{array}{l}\text { Daily given } 4 \mathrm{~d} \text { before and } 3 \mathrm{~d} \text { after } \\
\text { challenge }\end{array}$ & $\begin{array}{l}\text { Full protection, human } \\
\text { equivalent dosing }\end{array}$ \\
\hline
\end{tabular}

TCID, tissue culture infectious dose. 
and could add to the overall effectiveness of PrEP. Attenuated acute viremia might also reduce early $\mathrm{CD}^{+} \mathrm{T}$ cell depletion, help to preserve immune function, and attenuate the course of HIV infection (Mehandru et al. 2004).

Animal models have also been used to explore the efficacy of intermittent drug dosing with TFV or Truvada. Intermittent PrEP can reduce the risks of drug toxicities, increase adherence, minimize drug-resistance emergence, and be more cost effective. Both FTC-TP and TFV-DP have long ( 40 to $>100 \mathrm{~h}$ ) intracellular half-lives in humans and can potentially achieve extended prophylactic activity when administered intermittently (Wang et al. 2004; Hawkins et al. 2005; Pruvost et al. 2005). Intermittent PrEP regimens of TDF or Truvada can be designed to be exposure driven or to follow a fixed schedule. Studies in macaques showing protection from oral or rectal SIV/SHIV exposures by a two-dose subcutaneous regimen containing TFV or TFV/FTC have provided the first proof-of-concept evidence for intermittent PrEP (Van Rompay et al. 1998; GarciaLerma et al. 2008). However, the high drug doses and subcutaneous drug delivery might have overestimated efficacy in both studies. More recent work using human equivalent doses of Truvada showed that macaques can be protected from rectal SHIV infection by several PrEP modalities, including a single oral dose given 1-7 $\mathrm{d}$ before exposure, followed by a second dose $2 \mathrm{~h}$ after exposure (Garcia-Lerma et al. 2010). Exposure-driven prophylactic modalities initiated around the time of exposure also maintained protection. These studies showed that intermittent PrEP, particularly with long-acting ARV drugs, can be highly effective and have a wide window of protection. They strengthen the possibility of developing feasible, cost-effective strategies to prevent HIV transmission in humans.

\section{HUMAN CLINICAL TRIALS}

A number of challenges currently exist for human HIV prevention trials. Unlike antiretroviral treatment efficacy (with HIV RNA concentrations and $\mathrm{CD} 4^{+} \mathrm{T}$ cell counts), there is
HIV Prevention by Oral Preexposure Prophylaxis

currently no surrogate marker to use in place of new HIV infections. Therefore, prevention trials must enroll thousands of participants, followed for several years, at significant expense, in order to document efficacy. Additionally, the regulatory environment for demonstrating safe and effective marketable prevention strategies is not well defined.

However, a number of clinical studies have been initiated in multiple at-risk populations with standard dosing of TDF with or without FTC. As of February 2011, nine oral PrEP trials enrolling $>22,000$ participants are at varying stages of completion (Table 2). The at-risk populations in these studies are heterosexual men and women, men who have sex with men (MSM), and intravenous drug users (IDUs). All trials are using TDF-containing products, either alone or in combination with FTC, and all are evaluating daily use with the exception of one pilot study of intermittent PrEP.

The first phase II safety study of daily TDF among 936 high-risk women in Ghana, Nigeria, and Cameroon for up to 12 mo saw no differences in adverse events or grade- 3 or -4 laboratory abnormalities between placebo and TDF users (Peterson al. 2007).

The second clinical study to be published evaluated daily use of the fixed-dose combination of TDF + emtricitabine (Truvada) in men who have sex with men. A total of 2499 gay and bisexual men, other MSM, and transgender women at high risk of HIV infection participated in the six-country, four-continent preexposure prophylaxis initiative ( $\mathrm{iPrEx}$ study). In this study, daily use of Truvada reduced HIV acquisition by 44\% (Grant et al. 2010). Based on drug concentrations in plasma and cryopreserved peripheral blood mononuclear cell cultures (PBMCs), a substantial number of subjects only appeared to be taking their drug sporadically. In those subjects who were $\geq 90 \%$ adherent by pill counts, drug exposure, and self-report, Truvada conferred $68 \%$ protection against HIV acquisition (Celum 2011). Truvada was safe and generally well tolerated, with higher rates of nausea and weight loss during the first $4 \mathrm{wk}$ of treatment compared with placebo. The overall rate of side effects was 
W. Heneine and A. Kashuba

Table 2. Summary of clinical trials investigating oral antiretrovirals for HIV prevention and expected dates of results publication

\begin{tabular}{|c|c|c|}
\hline 2010 & 2011 & $2012+$ \\
\hline $\begin{array}{l}\text { iPrEx } \\
\text { Phase III trial of once-daily } \\
\text { oral TDF/FTC (Brazil, } \\
\text { Ecuador, Peru, South Africa, } \\
\text { Thailand, United States) } \\
\text { Showed that once-daily TDF/ } \\
\text { FTC reduced risk of HIV } \\
\text { infection in gay men, } \\
\text { transgender women, and other } \\
\text { men who have sex with men an } \\
\text { average of } 43.8 \% \text {. }\end{array}$ & $\begin{array}{l}\text { FEM-PrEP } \\
\text { Phase III trial of a once-daily dose } \\
\text { of TDF/FTC (Kenya, South Africa, } \\
\text { Tanzania) } \\
\text { Study's data review committee } \\
\text { determined that the trial would not } \\
\text { be able to answer the question of } \\
\text { whether the study drug decreased } \\
\text { risk of HIV infection among } \\
\text { HIV-negative women at risk via } \\
\text { sexual transmission. The study will } \\
\text { be discontinued. }\end{array}$ & $\begin{array}{l}\text { Partners PrEP } \\
\text { Phase III trial of once-daily oral } \\
\text { TDF and once-daily oral TDF/ } \\
\text { FTC (Kenya, Uganda) }\end{array}$ \\
\hline \multirow[t]{2}{*}{$\begin{array}{l}\text { CDC } 4323 \\
\text { Phase II trial of once-daily oral } \\
\text { TDF (United States) } \\
\text { The trial reported no serious } \\
\text { adverse events and preliminary } \\
\text { data show PrEP use did not } \\
\text { have a significant effect on HIV } \\
\text { risk behavior. Additional data } \\
\text { expected in } 2011 .\end{array}$} & $\begin{array}{l}\text { CDC } 4940 \text { (TDF2) } \\
\text { Phase II trial of once-daily } \\
\text { TDF/FTC (Botswana) }\end{array}$ & $\begin{array}{l}\text { VOICE (MTN-003) } \\
\text { Phase IIb trial of once-daily oral } \\
\text { TDF, once-daily oral TDF/FTC, } \\
\text { and } 1 \% \text { tenofovir gel (South } \\
\text { Africa, Uganda, Zimbabwe). This } \\
\text { study has fully enrolled. }\end{array}$ \\
\hline & $\begin{array}{l}\text { IAVI E001 and E002 in Kenya } \\
\text { and Uganda } \\
\text { This study is evaluating the safety } \\
\text { and acceptability of } \\
\text { intermittent and daily PrEP } \\
\text { regimens using TDF/FTC. } \\
\text { This study has completed. }\end{array}$ & $\begin{array}{l}\text { ATN } 082 \\
\text { An exploratory mixed-methods } \\
\text { study comparing behavioral } \\
\text { interventions alone and combined } \\
\text { with daily TDF/FTC }\end{array}$ \\
\hline
\end{tabular}

very similar in both the FTC-TDF and placebo groups, and severe side effects were rare.

Most recently, however, a trial in women using daily dosing of Truvada (FEM-PrEP) was halted for futility: It was determined that substantial HIV prevention (i.e., >30\%) could not be attained with daily use of Truvada (Matassa 2011; Roehr 2011). As of May 2011, the study is undergoing orderly closure, and sample and data analysis will determine whether this result was because of a biological process (e.g., increased genital tract inflammation in this population), adherence, or differential drug exposure in genital tract tissues (as discussed above).

In contrast to FEM-PrEP, interim results from two studies, the Partners PrEP trial and TDF2 (CDC 4940), have demonstrated clear efficacy in reducing HIV acquisition. In the Partners PrEP, both daily TDF and FTC/TDF reduced HIV risk by $62 \%$ and $73 \%$, respectively, in both men and women, and the effects in women and men were statistically similar (Baeten 2011). The study is continuing with two active arms only to gather additional comparative information. Likewise, results of the TDF2 trial among heterosexual 
participants in Botswana showed that daily FTC/TDF provided an overall protective efficacy of $62.6 \%$ (Thigpen 2011). Limiting analysis to participants on study medication when infected, the protective efficacy was $77.9 \%$.

Looking beyond tenofovir and emtricitabine, next-generation PrEP drugs are being evaluated, including maraviroc (a CCR5 receptor antagonist) and TMC278 (a long-acting NNRTI).

Finally, intermittent PrEP is being considered as an attractive strategy. Daily dosing may not be practical for individuals who are only occasionally exposed to high-risk encounters, which can subsequently result in decreased rates of adherence to medication regimens (prophylaxis fatigue) and unnecessary systemic toxicity. A preliminary clinical study in Kenya and Uganda is currently under way among 150 serodiscordant couples to evaluate the safety and acceptability of iPrEP (http://www.iavi.org). In this investigation, subjects will take standard doses of oral TDF/FTC once daily or intermittently (defined as twice weekly plus coitusrelated dosing). Samples for blood plasma and intracellular concentrations will be obtained.

\section{FUTURE DIRECTIONS AND CHALLENGES}

Based on the results of iPrEX, the Centers for Disease Control and Prevention has issued interim guidance for PrEP use among MSMs and has begun with other U.S. Public Health Service (PHS) agencies to develop PHS guidelines on the use of PrEP for MSM at high risk for HIV infection (Centers for Disease Control 2011). However, until the safety and efficacy of PrEP is determined in trials now under way with populations at high risk for HIV acquisition by other routes of transmission, PrEP should be considered only for MSM. The iPrEX trial results that showed a substantially higher efficacy ( $\sim 68 \%)$ among adherent participants with detectable ARV drugs provide strong evidence that support for adherence to the ARV regimen must be a routine component of any PrEP program. To minimize the risk for drug resistance, PrEP should not be started in persons with signs or symptoms of acute viral infection unless
HIV Prevention by Oral Preexposure Prophylaxis

HIV-uninfected status is confirmed. Despite the indications of biologic effectiveness, the implementation of PrEP will need to overcome many challenges to provide a meaningful benefit at the population level. Mathematical models have suggested that the effectiveness of PrEP may be offset by low uptake, suboptimal adherence, and risk compensation, which refers to increases in HIV risk behavior among PrEP users on the assumption that they are protected against HIV infection (Abbas et al. 2007; Desai et al. 2008; Paltiel et al. 2009). As was the case during the implementation of ARV for treating HIV infections, plans for PrEP implementation will likely include multiple components on optimal drug delivery, safety screening, behavioral intervention, integration of PrEP as part of comprehensive care, and monitoring the impact of PrEP at the population level (Underhill et al. 2011). The promise of PrEP also raises important research questions. These range from the development and evaluation of next-generation PrEP agents and modalities including episodic dosing, new drug classes and combinations, and long-acting formulations, to the assessment of risks of PrEP-induced drug resistance (Supervie et al. 2010).

\section{REFERENCES}

* Reference is also in this collection.

Abbas UL, Anderson RM, Mellors JW. 2007. Potential impact of antiretroviral chemoprophylaxis on HIV-1 transmission in resource-limited settings. PLoS One 2: e875. doi: 10.1371/journal.pone.0000875.

Baeten J, Colem C. 2011. Antiretroviral pre-exposure prophylaxis for HIV-1 prevention among heterosexual African men and women: The partners PrEP study. In The 6th International AIDS Society Conference on HIV Pathogenesis, Treatment and Prevention. Rome.

Berger EA, Murphy PM, Farber JM. 1999. Chemokine receptors as HIV-1 coreceptors: Roles in viral entry, tropism, and disease. Annu Rev Immunol 17: 657-700.

Brown KC, Patterson KB, Malone SA, Shaheen NJ, Prince HM, Dumond JB, Spacek MB, Heidt PE, Cohen MS, Kashuba AD. 2011. Single and multiple dose pharmacokinetics of maraviroc in saliva, semen, and rectal tissue of healthy HIV-negative men. J Infect Dis 203: 1484-1490.

Celum C. 2011. Drugs for prevention-topical and systemic PrEP. In 18th Conference on Retroviruses and Opportunistic Infections, Boston.

Centers for Disease Control 2011. Interim guidance: Preexposure prophylaxis for the prevention of HIV infection 
W. Heneine and A. Kashuba

in men who have sex with men. MMWR Morb Mortal Wkly Rep 60: 65-68.

Chun TW, Engel D, Berrey MM, Shea T, Corey L, Fauci AS. 1998. Early establishment of a pool of latently infected, resting $\mathrm{CD}^{+}{ }^{+} \mathrm{T}$ cells during primary HIV-1 infection. Proc Natl Acad Sci 95: 8869-8873.

Cohen MS, Gay C, Kashuba AD, Blower S, Paxton L. 2007. Narrative review: Antiretroviral therapy to prevent the sexual transmission of HIV-1. Ann Intern Med 146: $591-601$.

Collins KB, Patterson BK, Naus GJ, Landers DV, Gupta P. 2000. Development of an in vitro organ culture mode to study transmission of HIV-1 in the female genital tract. Nat Med 6: 475-479.

Denton PW, Estes JD, Sun Z, Othieno FA, Wei BL, Wege AK, Powell DA, Payne D, Haase AT, Garcia JV. 2008. Antiretroviral pre-exposure prophylaxis prevents vaginal transmission of HIV-1 in humanized BLT mice. PLoS Med 5: e16. doi: 10.1371/journal.pmed.0050016.

Department of Health and Human Services Panel on Antiretroviral Guidelines for Adults and Adolescents (January 10, 2011). Guidelines for the use of antiretroviral agents in HIV-1-infected adults and adolescents, pp. $1-166$.

Desai K, Sansom SL, Ackers ML, Stewart SR, Hall HI, Hu DJ, Sanders R, Scotton CR, Soorapanth S, Boily MC, et al. 2008. Modeling the impact of HIV chemoprophylaxis strategies among men who have sex with men in the United States: HIV infections prevented and costeffectiveness. AIDS 22: 1829-1839.

Dumond JB, Yeh RF, Patterson KB, Corbett AH, Jung BH, Rezk NL, Bridges AS, Stewart PW, Cohen MS, Kashuba AD. 2007. Antiretroviral drug exposure in the female genital tract: Implications for oral pre- and post-exposure prophylaxis. AIDS 21: 1899-1907.

Dumond JB, Patterson KB, Pecha AL, Werner RE, Andrews E, Damle B, Tressler R, Worsley J, Kashuba AD. 2009. Maraviroc concentrates in the cervicovaginal fluid and vaginal tissue of HIV-negative women. J Acquir Immune Defic Syndr 51: 546-553.

Garcia-Lerma JG, Otten RA, Qari SH, Jackson E, Cong ME, Masciotra S, Luo W, Kim C, Adams DR, Monsour M, et al. 2008. Prevention of rectal SHIV transmission in macaques by daily or intermittent prophylaxis with emtricitabine and tenofovir. PLoS Med 5: e28. doi: 10.1371/journal.pmed.0050028.

Garcia-Lerma JG, Cong ME, Mitchell J, Youngpairoj AS, Zheng Q, Masciotra S, Martin A, Kuklenyik Z, Holder A, Lipscomb J, et al. 2010. Intermittent prophylaxis with oral truvada protects macaques from rectal SHIV infection. Sci Transl Med 2: 14ra4. doi: 10.1126/ scitranslmed.3000391.

Grant RM, Lama JR, Anderson PL, McMahan V, Liu AY, Vargas L, Goicochea P, Casapia M, Guanira-Carranza JV, Ramirez-Cardich ME, et al. 2010. Preexposure chemoprophylaxis for HIV prevention in men who have sex with men. N Engl J Med 363: 2587-2599.

Haase A. 2005. Perils at the mucosal front lines for HIV and SIV and their hosts. Nature Rev Immunol 5: 783-792.

Hawkins T, Veikley W, St Claire RL III, Guyer B, Clark N, Kearney BP. 2005. Intracellular pharmacokinetics of tenofovir diphosphate, carbovir triphosphate, and lamivudine triphosphate in patients receiving triplenucleoside regimens. J Acquir Immune Defic Syndr 39: 406-411.

Hu J, Gardner MB, Miller CJ. 2000. Simian immunodeficiency virus rapidly penetrates the cervicovaginal mucosa after intravaginal inoculation and infects intraepithelial dendritic cells. J Virol 74: 6087-6095.

Jones AE, Talameh JA, Patterson KB, Rezk N, Prince H, Kashuba ADM. 2009. First-dose and steady-state pharmacokinetics of raltegravir in the genital tract of HIV negative women. In 10th International Workshop on Clinical Pharmacology of HIV Therapy. Amsterdam.

Keele BF, Derdeyn CA. 2009. Genetic and antigenic features of the transmitted virus. Curr Opin HIV AIDS 4: 352-357.

Keele BF, Giorgi EE, Salazar-Gonzalez JF, Decker JM, Pham KT, Salazar MG, Sun C, Grayson T, Wang S, Li H, et al. 2008. Identification and characterization of transmitted and early founder virus envelopes in primary HIV-1 infection. Proc Natl Acad Sci 105: 7552-7557.

Li Q. 2009. Glycerol monolaurate prevents mucosal SIV transmission. Nature Rev Immunol 458: 1034-1038.

Li Q, Estes JD, Schlievert PM, Duan L, Brosnahan AJ, Southern PJ, Reilly CS, Peterson ML, Schultz-Darken N, Brunner KG, et al. 2009. Glycerol monolaurate prevents mucosal SIV transmission. Nature 458: 1034-1038.

Matassa M. 2011. FHI statement on the FEM-PrEP HIV prevention study: FHI to initiate orderly closure of FEM-PrEP. http://www.fhi.org/en/AboutFHI/Media/ Releases/FEM-PrEP_statement041811.htm.

Mehandru S, Poles MA, Tenner-Racz K, Horowitz A, Hurley A, Hogan C, Boden D, Racz P, Markowitz M. 2004. Primary HIV-1 infection is associated with preferential depletion of $\mathrm{CD} 4^{+} \mathrm{T}$ lymphocytes from effector sites in the gastrointestinal tract. J Exp Med 200: 761-770.

Miller CJ, Li Q, Abel K, Kim EY, Ma ZM. 2005. Propagation and dissemination of infection after vaginal transmission of simian immunodeficiency virus. J Virol 79: 92179227.

Neff CP, Ndolo T, Tandon A, Habu Y, Akkina R. 2010. Oral pre-exposure prophylaxis by anti-retrovirals raltegravir and maraviroc protects against HIV-1 vaginal transmission in a humanized mouse model. PLoS One 5: e15257. doi: 10.1371/journal.pone.0015257.

Nicol MR, Kashuba AD. 2010. Pharmacologic opportunities for HIV prevention. Clin Pharmacol Ther 88: 598-609.

Otten RA, Adams DR, Kim CN, Jackson E, Pullium JK, Lee K, Grohskopf LA, Monsour M, Butera S, Folks TM. 2005. Multiple vaginal exposures to low doses of R5 simianhuman immunodeficiency virus: Strategy to study HIV preclinical interventions in nonhuman primates. J Infect Dis 191: 164-173.

Padian NS, Buve A, Balkus J, Serwadda D, Cates W Jr. 2008. Biomedical interventions to prevent HIV infection: Evidence, challenges, and way forward. Lancet 372: 585-599.

Paltiel AD, Freedberg KA, Scott CA, Schackman BR, Losina E, Wang B, Seage GR III, Sloan CE, Sax PE, Walensky RP. 2009. HIV preexposure prophylaxis in the United States: Impact on lifetime infection risk, clinical outcomes, and cost-effectiveness. Clin Infect Dis 48: 806-815. 
Patterson K, Prince H, Kraft E, Jones A, Paul S, Shaheen N, Spacek M, Heidt P, Reddy S, Rooney J, et al. 2010. Exposure of extracellular and intracellular tenofovir and emtricitabine in mucosal tissues after a single fixed dose of TDF/FTC: Implications for pre-exposure HIV prophylaxis (PrEP). XVIII International AIDS Conference, Vienna, Austria.

Peterson L, Taylor D, Roddy R, Belai G, Phillips P, Nanda K, Grant R, Clarke EE, Doh AS, Ridzon R, et al. 2007. Tenofovir disoproxil fumarate for prevention of HIV infection in women: A phase 2, double-blind, randomized, placebo-controlled trial. PLoS Clin Trials 2: e27. doi: 10.1371/journal.pctr.0020027.

Pruvost A, Negredo E, Benech H, Theodoro F, Puig J, Grau E, Garcia E, Molto J, Grassi J, Clotet B. 2005. Measurement of intracellular didanosine and tenofovir phosphorylated metabolites and possible interaction of the two drugs in human immunodeficiency virus-infected patients. Antimicrob Agents Chemother 49: 1907-1914.

Reynolds MR, Rakasz E, Skinner PJ, White C, Abel K, Ma Z-M, Compton L, Napoé G, Wilson N, et al. 2005. $\mathrm{CD}^{+}$T-lymphocyte response to major immunodominant epitopes after vaginal exposure to simian immunodeficiency virus: Too late and too little. J Virol 79: 9228 9235.

Roehr B. 2011. HIV prevention trial in women is abandoned after drugs show no impact on infection rates. $B M J 342$ : d2613. doi: 10.1136/bmj.d2613.

Salas Herrera IG, Pearson RM, Turner P 1991. Quantitation of albumin and $\alpha$-1-acid glycoprotein in human cervical mucus. Hum Exp Toxicol 10: 137-139.

* Shaw GM, Hunter E. 2011. HIV transmission. Cold Spring Harb Perspect Biol doi: 10.1101/cshperspect.a006965.

Subbarao S, Otten RA, Ramos A, Kim C, Jackson E, Monsour M, Adams DR, Bashirian S, Johnson J, Soriano V et al. 2006. Chemoprophylaxis with tenofovir disoproxil fumarate provided partial protection against infection with simian human immunodeficiency virus in macaques given multiple virus challenges. J Infect Dis 194: 904-911.

Supervie V, García-Lerma JG, Heneine W, Blower S. 2010. HIV, transmitted drug resistance, and the paradox of preexposure prophylaxis. Proc Natl Acad Sci 107: 1238112386.
HIV Prevention by Oral Preexposure Prophylaxis

Thigpen MC, Kebaabetswe PM, Smith DK, Segolodi TM, Soud FA, Chillag K, Chirwa LA, Kasonde M, Mutanhaurwa R, Henderson FL. 2011. Daily oral antiretroviral use for the prevention of HIV infection in heterosexually active young adults in Botswana: Results from the TDF2 study. In The 6th Annual International AIDS Society Conference on HIV Pathogenesis, Treatment and Prevention. Rome.

Tsai CC, Follis KE, Sabo A, Beck TW, Grant RF, Bischofberger N, Benveniste RE, Black R. 1995. Prevention of SIV infection in macaques by $(R)-9$-(2-phosphonylmethoxypropyl)adenine. Science 270: 1197-1199.

Tsai CC, Emau P, Follis KE, Beck TW, Benveniste RE, Bischofberger N, Lifson JD, Morton WR. 1998. Effectiveness of postinoculation (R)-9-(2-phosphonylmethoxypropyl) adenine treatment for prevention of persistent simian immunodeficiency virus SIV $_{\text {mne }}$ infection depends critically on timing of initiation and duration of treatment. J Virol 72: 4265-4273.

UNAIDS. 2009. Global Facts \& Figures. Joint United Nations Programme on HIV/AIDS.

Underhill K, Operario D, Skeer M, Mimiaga M, Mayer K. 2011. Packaging PrEP to prevent HIV: An integrated framework to plan for pre-exposure prophylaxis implementation in clinical practice. J Acquir Immune Defic Syndr 55: 8-13.

Van Rompay KK, Berardi CJ, Aguirre NL, Bischofberger N, Lietman PS, Pedersen NC, Marthas ML. 1998. Two doses of PMPA protect newborn macaques against oral simian immunodeficiency virus infection. Aids 12: F79-F83.

Van Rompay KK, Kearney BP, Sexton JJ, Colon R, Lawson JR, Blackwood EJ, Lee WA, Bischofberger N, Marthas ML. 2006. Evaluation of oral tenofovir disoproxil fumarate and topical tenofovir GS-7340 to protect infant macaques against repeated oral challenges with virulent simian immunodeficiency virus. J Acquir Immune Defic Syndr 43: 6-14.

Veazey RS, Springer MS, Marx PA, Dufour J, Klasse PJ, Moore JP. 2005. Protection of macaques from vaginal SHIV challenge by an orally delivered CCR5 inhibitor. Nat Med 11: 1293-1294.

Wang LH, Begley J, St Claire RL III, Harris J, Wakeford C, Rousseau FS. 2004. Pharmacokinetic and pharmacodynamic characteristics of emtricitabine support its once daily dosing for the treatment of HIV infection. AIDS Res Hum Retroviruses 20: 1173-1182. 


\section{$\$ \mathrm{CSH} \&$ Cold Spring Harbor

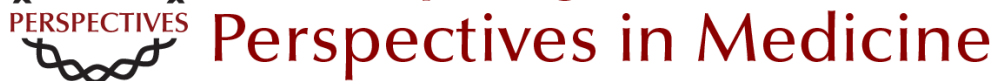

\section{HIV Prevention by Oral Preexposure Prophylaxis}

Walid Heneine and Angela Kashuba

Cold Spring Harb Perspect Med 2012; doi: 10.1101/cshperspect.a007419 originally published online December 6, 2011

\section{Subject Collection HIV}

HIV Pathogenesis: Dynamics and Genetics of

Viral Populations and Infected Cells John Coffin and Ronald Swanstrom

Human Immunodeficiency Virus Vaccine Trials Robert J. O'Connell, Jerome H. Kim, Lawrence Corey, et al.

HIV Transmission George M. Shaw and Eric Hunter

Novel Cell and Gene Therapies for HIV James A. Hoxie and Carl H. June

Behavioral and Biomedical Combination Strategies for HIV Prevention Linda-Gail Bekker, Chris Beyrer and Thomas C. Quinn

HIV-1 Assembly, Budding, and Maturation Wesley I. Sundquist and Hans-Georg Kräusslich

HIV-1 Assembly, Budding, and Maturation Wesley I. Sundquist and Hans-Georg Kräusslich

Lessons in Nonhuman Primate Models for AIDS Vaccine Research: From Minefields to Milestones Jeffrey D. Lifson and Nancy L. Haigwood
HIV-1 Pathogenesis: The Virus

Ronald Swanstrom and John Coffin

The T-Cell Response to HIV

Bruce Walker and Andrew McMichael

HIV-1 Reverse Transcription Wei-Shau Hu and Stephen H. Hughes

HIV Pathogenesis: The Host A.A. Lackner, Michael M. Lederman and Benigno Rodriguez

HIV: Cell Binding and Entry Craig B. Wilen, John C. Tilton and Robert W. Doms

Innate Immune Control of HIV Mary Carrington and Galit Alter

HIV DNA Integration

Robert Craigie and Frederic D. Bushman

HIV-1-Related Central Nervous System Disease: Current Issues in Pathogenesis, Diagnosis, and Treatment Serena Spudich and Francisco González-Scarano

For additional articles in this collection, see http://perspectivesinmedicine.cshlp.org/cgi/collection/ 